\title{
HISTOLOGICAL STUDIES ON SOME EGYPTIAN CLOVER GENOTYPES ATTACHED WITH DODDER (Cuscuta spp.) El-Refaey, R. A. ${ }^{1}$; E. H. El-Seidy'; I. E. Soliman²; Samira A. Fouad ${ }^{3}$ and Shereen M. El-Nahrawy ${ }^{4}$ \\ 1- Agronomy Dept., Faculty of Agriculture, Tanta Univ., Egypt. \\ 2- Weed Res. Central Lab., Agric. Res.Cent., Giza, Egypt. \\ 3- Botany Dept., Faculty of Agriculture, Kafr El-Sheikh Univ., Egypt. \\ 4- Forage Crops Res. Dept., Field Crops Res. Inst., ARC, Egypt.
}

\section{ABSTRACT}

Three field experiments were carried out at Sakha Agricultural Research Station Farm, Kafer El-Sheikh Governorate, ARC, Egypt, during three successive winter seasons of 2008/09,2009/10 and 2010/11, to investigate the performance of some egyption clover genotype for its resistance/tolerance to dodder infestation. Anatomical structures as well as biochemical analyses for berseem plants were carried out to identify variation in the correlated traits with tolerance to dodder infestation. The results indicated that genotypes no. 35 and 65 showed that the moderate genotypes behaved different, the parasite is scarcely able to pierce the epidermis but lignifications of host pericycle and starch sheath showed incompatible interaction between clover genotypes and $C$. planiflora. The sensitive genotypes no. 29 and 94 were in contrast compatible with the parasite, the infection developed normally with the intrusive cells reaching the center cylinder and the host vascular tissues.

The results indicated that the amount of phenolic acids is relatively high; 1111.65 and $965.24 \mu \mathrm{g} / 100 \mathrm{mg}$ of foliage dry weight for genotypes; Helali and no. 51 respectively. These two genotypes could retain some tolerance to the infestation with C. planiflora. Whereas, the phenolic acids in the genotypes no. 35 and 74 which are considered to some extent retain moderate tolerance to infestation with dodder were present in lesser concentration (784.6 and $735.38 \mu \mathrm{g} / 100 \mathrm{mg}$ ). While, Genotypes no. 94 and 29 which could be considered susceptible to infestation with dodder, phenolic acids were found in trace amounts (386.64 and $423.02 \mu \mathrm{g} / 100 \mathrm{mg}$ ), respectively. HPLC analysis revealed the presence of protocatechuic acid, caffeic acid, P-hydroxyl benzoic acid, coumaric acid, ferulic acid, vanllic acid and syringic acid and their concentrations were different from berseem genotype to another.

The obtained results may be encouraging to use the tolerant genotypes, which had the least reduction percentages due to dodder infestation, for developing compost or synthetic cultivar(s) which retain tolerance to dodder infestation. This cultivar could be used by itself as a way of control of dodder in farmers' fields or integrated with the other factors of dodder control.

\section{INTRODUCTION}

Egyptian clover or berseem (Trifolium alexandrinum L.) is a winter annual legume widely grown in several countries for fresh fodder, hay and silage. Unfortunately, the uncertified and uncontrolled local seeds may contaminated with dodder (Cuscuta spp.) seeds, which affect negatively both productivity and quality of produced forage.Anatomically, resistance/tolerance to dodder could be attributed to a number of factors, viz. initiation of cambial cells in China rose (Dorr, 1987); hypersensitive reaction in tomato (Al- 
Menoufi and Ashton, 1991) and lignified cells unsheathing the vascular bundle in grasses (Joel et al., 1996) and thickened epidermal cells and lignified hypodermal cells (Farah and El-Hassan, 2002) in grasses. The haustorium lightly contacted with the host was formed by the expansion of the epidermis and cortex of the stem at the contact side and to have a group of meristmatic cells within the hasutorial cortex (Lee, 1985). The dodder adheres to host with a cementing layer of pectin and develops houstoria within a few days due to thigmotropic responses and chemical recognition of the host plant to the houstoria (Press et al., 1990). They added that's single cell hyphen elongates within the host tissue and meets the vascular bundles. In chickpea Abd El-Wahed (1996) found that, the haustorium of Cuscuta spp. expanded to the cortex, whilst, in Egyptian clover, the expansion was evident in the vascular cylinder. Hegazy et al. (2005) found that the ratios of palisade to spongy tissue were significantly higher in control than in treated plants reaching 5.36 in Diplotaxis acris control plants. Moreover, the influence of mulching treatment on the hydraulic conductance of the petiole became more obvious when the leaf area was involved leaf specific conductance (LSC) and significantly higher LSC in treated than in control plants were obtained in $D$. acris, Plantago phaeostoma and Tricodesma africanum. Furthermore, Rasmussen et al.; (2004) explained that, the root tip cells subjected to the alkaloids; gramine and hordenine caused damages to the cell walls, disorganization of organelles, increase cell vacuoles and the appearance of lipid and globules, showing food reserves. Leather and Einhellig (1985) stated that the common allele-chemicals include phenolics like cinnamic, benzoic acids, coumarines, tannins and flavonoids, terpenoids, a few alkaloids, steroids, and quinones. Also, among the natural products, Liu and Lovett (1993) have been encountered in allelopathic interactions are the phenolic acids, flavonoids, tannins, alkaloids, terpenoids and glucosinolates. Otherwise, Kim and Shin (2003) reported that until recently, many studies verified the mechanisms of a self-defense system, including allelopathy in plants, particularly phenylpropanoid and isoterpenoid metabolism. The increase of allelopathic phenolic and terpenoid compounds under environmental stresses has been well documented, for example, enhanced UV-B- light induces the accumulation of phenylpropanoids and flavanoids in different plant species, such as bean, parsley, potato, tomato, maize, rye, barley and rice. In addition, Khanh et al. (2007) found that numerous phytotoxins such as cytokinins, diterpenoids, fatty acids, flavones, glucopyranosides, indoles, momilactones (A and B), oryzalexins, phenols, phenolic acids, resorcinols and stigmastanols have been identified and determined as growth inhibitors in rice. Through laboratory studies, Hall and Henderlong (1989) found that the auto-toxic compound contained within the water-extractable alfalfa fraction, and was not the direct result of microbial activity. Ascending paper chromatographic separation indicated that the autotoxic compound had reading fraction (RF) characterization similar to phenolic acids. Also, water-soluble auto-toxic compound had characteristics indicative of phenolic compounds. Also, Mattice et al. (1997) showed significantly higher levels of 3-hydroxy benzoic acid (3 HBA), 4-hydroxy benzoic acid (4 HBA), and 3.4-dihydroxyhydro-cinamic acid (3.4 DHHCA) and tentatively 
identified 4-hydroxy phenyl acetic acid (4 HPAA) in water from allelepathic rice cultivars when compared with water from the non-allelopathic cultivar rexmund. All these chemicals are phenolic acids which have been described as allelo-chemicals in many plant species. Kim et al. (2000) identified several compounds by $\mathrm{Gc} / \mathrm{Ms}$ analysis from rice cultivar Kouketsumochi such as sterols, benzaldehydes, benzene derivatives, long-chain fatty acid, esters, aldehydes, ketones and amines from fractions with biological activity. Whereas, Rimando et al. (2001) found that Taichung Native 1, allelopathic rice; have been identified by the bioassay-guided isolation method. Its allelechemicals are azelaic acid, P-coumaric acid, $1 \mathrm{H}$-indole-carboxaldehyde, $1 \mathrm{H}$ indole-3-carboxylic acid, $1 \mathrm{H}$-indole-5- carboxylic acid and 1, 2benzenedicarboxylic acid bis (2- ethylhexyl) ester. Also, Chung et al. (2002) demonstrated that $p$-hydroxybenzoic, $p$-coumaric acids were the most active compounds in rice hull extracts which have inhibitory effect on the growth of barnyard grass seedlings. High-performance liquid chromatography, chlorogenic acid and trans-cinnamic acid were quantified as having the highest amounts in the water and EtOAc fractions, respectively (Chon, 2004). In nutgrass (Cyperus rotundus), Ali (2005) mentioned that tuber and foliage contained different flavonoids and phenolic compounds such as rutin, kaempferol, quercetin, myricetin, p-hydroxybenzoic, chlorogenic acid and ferulic acids. While, in rice, Noguchi and Ino (2005) found that the putative compound causing the inhibitory effect of rice seedlings isolated from their culture solution and purified with several chromatographies. The chemical structure of the inhibitor was determined by spectral data as 3, 20-epoxy-3 alpha -hydroxy-9 beta -pimara-7, 15-dien-19, 6 beta-olide (momilactone B). Momilactone $B$ inhibited the root and shoot growth of cress seedlings at concentrations greater than $3 \mathrm{nmol} \mathrm{mL}-1$. The inhibition was increased with increasing concentrations of momilactone $\mathrm{B}$. Momilactone $\mathrm{B}$ was released into the neighboring environment from rice roots throughout its life cycle.

Therefore, the objective of the study was to investigate into the cellular and biochemical events involved in the resistance/tolerance of berseem clover (Trifolium alexandrinum L.) to a parasitic higher plant (Cuscuta spp.).

\section{MATERIALS AND METHODS}

Three field experiments were carried out at Sakha Agricultural Research Station Farm, Kafer El-Sheikh Governorate, Forage Crops Research Department (FCRD), Field Crops Research Institute (FCRI), Agricultural Research Center (ARC), Egypt, during three successive winter seasons of 2008/09, 2009/10 and 2010/11 to investigate the performance of some Egyptian clover genotypes (Trifolium alexandrinum $L$.) for forage yield and its tolerance to dodder infestation (Cuscuta planiflora).

\section{Anatomical structure investigation:-}

Stem samples were taken from $2^{\text {nd }}$ cut in $2^{\text {nd }}$ season $(1.00 \mathrm{~cm}$ long $)$ from the sub apical part of moderate stem tip of berseem plant. The samples were fixed 48 hours in FAA $(10.00 \mathrm{ml}$ formalin, $5.00 \mathrm{ml}$ glacial acid, $50.00 \mathrm{ml}$ ethyl alcohol absolute and $35.00 \mathrm{ml}$ distillated water). Samples were washed 
twice in $70 \%$ ethyl alcohol. Dehydration was done by passing the samples in a series of ethyl alcohol concentration (75-100\%) followed by three changes of absolute alcohol for four hours and each sample was passed through out of mixture of xylol and absolute alcohol; in the following percentages $25 \%$, $50 \%$ and $75 \%$ and pure xylem in at lastly two changes for four each dilution. Paraffin shavings reagent containing samples until saturation within 12 hours, two changes of Paraffin were done to get rid of all traces of xylol. Samples were taken, embedded in melted Paraffin in embedding paper trays, and then cooled rapidly with cold water. Sections (10-12 microns thick) were done with Rotary Microtome (Leica RM 2125 apparatus), Paraffin sections were fixed to the slides with albumin. Slides were left to complete dryness for 24 hours on dry oven at $50^{\circ} \mathrm{C}$. Before staining, the slides were placed in two changes of xylol for 10 times, and then transferred to a jar containing equal parts of absolute alcohol and xylol for 5 minutes. The sections were plunged in close series of descending dilutions of ethyl alcohol ranged from absolute to $5 \%$ for 5 minutes. Then Sections were stained for 10 minutes in a jar containing $1 \%$ Safranin, and then the excess stain was washed. Sections were stained for 1 minute in a jar containing $1 \%$ light green. Sections were then cleared in xylol and mounted in Canada Balsam and prepared for microscopic examination (Ruzin, 1991). Five reading for each slide were examined with electric microscope (Leica DM LS) with digital camera (Leica DC300) and then photographed.

\section{Biochemical analysis of clover plants:}

Dry samples of clover plants at 40 days old from the $1^{\text {st }}$ cut were taken to determine total soluble phenols and phenol acids. Total phenolic compounds were determined calorimetrically according to the method reported by Snell and Snell (1953) using Folin-Ciocalteau phenol reagent. For estimation, $1 \mathrm{ml}$ of ethanol extract was mixed with 10 drops of concentrated hydrochloric acid, heated rapidly in boiling water bath for 10 minutes, cooling, then $1 \mathrm{ml}$ of Folin-Ciocalteau reagent and $1.5 \mathrm{ml}$ of $14 \%$ sodium carbonate were added. The mixture was made up to $5 \mathrm{ml}$ by distilled water, shaken well, and then kept in a boiling water bath for 5 minutes. The developed color was measured at $650 \mathrm{~nm}$ against a reagent blank using SHIMADZU 240 UV/VIS spectrophotometer. Total soluble phenolic compounds were calculated as $\mathrm{mg} / \mathrm{g}$ fresh weight using standard curve with pyrogallol.

Identification of phenolic acids in donor plant species:

Vanillic, ferulic, syrungic, $p$-coumaric, $p$-hydroxypenzoic, caffic, gaalic acid and protocatoic were subsequently checked for purity by high pressure liquid chromatography (HPLC). HPLC grade water and $\mathrm{MeOH}$ were used for all analyses. Phosphoric acid buffer was made using HPLC grade $\mathrm{NH}_{4} \mathrm{H}_{2} \mathrm{PO}_{4}$ and $\mathrm{H}_{3} \mathrm{PO}_{4}$

\section{Phenolic extraction and hydrolysis:}

Water extract of each donor plant shoot was prepared, then phenolic extraction of phenolics in the water extract which found in glycon form were extracted as described by Mckeehen et al. (1999) with some modifications. Approximately, $15 \mathrm{ml}$ of $4 \mathrm{~N} \mathrm{NaOH}$ was added for $200 \mathrm{ml}$ of each concentration of water extract in $50 \mathrm{ml}$ Pyrex centrifuge tube purged with nitrogen and shaken for $2 \mathrm{~h}$ in dark with a wrist - action shaker. 
After phenolic acids liberated by alkaline hydrolysis, samples were acidified with ice - cold $6 \mathrm{~N} \mathrm{HCl}$ to reduce $\mathrm{pH}$ to between 1 and 2. Samples were centrifuged at $3000 \mathrm{rpm}$ and the supernatant was decanted into a $250 \mathrm{ml}$ separator funnel. The supernatant was extracted with ethyl acetate $(3 \times 50$ $\mathrm{ml}$ ) with shaking for $10 \mathrm{~s}$ and the mixture was allowed to settle for $5 \mathrm{~min}$ between extractions. Ethyl acetate fractions were collected and pooled. The remaining pellet was diluted with $15 \mathrm{ml}$ of distilled $\mathrm{H}_{2} \mathrm{O}$, vortex distributed and re-centrifuged at $3000 \mathrm{rpm}$. The second supernatant was re-extracted with ethyl acetate $(30 \times 50 \mathrm{ml})$ as before and all ethyl acetate fractions were pooled. The phenolic acids-rich ethyl acetate fraction was dried by addition of anhydrous sodium sulfate and concentrated using a rotary vacuum evaporator at $35^{\circ} \mathrm{C}$ to dryness. The phenolic acids rich residue was resolubilized in $2.5 \mathrm{ml}$ of $\mathrm{MeOH}$ and stored in a dark prior to separation and quantification by HPLC within $24 \mathrm{~h}$ of extraction.

HPLC analysis: phenolic acids were separated by Shimaduz (Kyoto, Japan) HPLC apparatus (model, LC-4A) equipped with visible / UV detector (model, SPD-2AS) at $280 \mathrm{~nm}$ and stainless steel column $(25.0 \mathrm{~cm} \times 4.6 \mathrm{~mm}$ i.d.) (Phenomenex Co., USA) coated with ODS, (RP-18). An aliquot of the sample suspended in $\mathrm{MeOH}$ was diluted with $10 \mathrm{mM}$ phosphoric acid buffer (PH3.5) to the same concentration as initial mobile phase $(15 \% \mathrm{MeOH})$. Samples were next filtered through a $0.2 \mu \mathrm{m}$ poly (tetrafluoroethylene) (PTFE) filter prior to injection. The two solvent systems consisted of $\mathrm{MeOH}(\mathrm{A})$ and $10 \mathrm{mM}$ phosphoric acid buffer, pH 3.5 (B), operated at follow rate of $1.50 \mathrm{ml} / \mathrm{min}$. The phosphoric acid buffer consisted of $10 \mathrm{mM} \mathrm{NH}_{4} \mathrm{H}_{2} \mathrm{PO}_{4}$ adjusted to $\mathrm{pH} 3.5$ with $10 \mathrm{mM} \mathrm{H}_{3} \mathrm{PO}$.

\section{RESULTS AND DISCUSSION}

\section{Histological studies on clover genotypes attached with dodder:}

The present experiment was conducted aiming to identify the site of parasitism of Cuscuta planiflora on eight tested berseem genotypes; (Helali and Genotypes no. 51, 35, 74, 65, 14, 94 and 29 and investigate if there is any histological differences existing which could be associated to specific berseem genotype or not. Cuscuta planiflora coil around stems of its hosts. The parasite is sending minute haustorium suckers into host tissues and drawing in nutrients. The haustorium of Cuscuta planiflora contacts stem at the sides of the host then penetrating expanding.

Different reactions of histological studies performed on sections of infested stems of berseem genotypes were illustrated in Figs. 1 and 2. These sections include accumulation of a brown substance that was observed around the penetration pathway of abortive houstoria in both the cortex and the vascular cylinder of the host stem. The substance covered the whole tissue and looked dark brown, almost black in thick sections, resembling the appearance of necrotic tissue. These results are in agreement with those of Fayaad et al. (1990) and Goldwasser et al. (2001) which illustrated that Cuscuta planfilora were coiling around stems of alfalfa crop and aster weed were completely blighted exhibiting shrank and then dark brown necrotic tissue. 


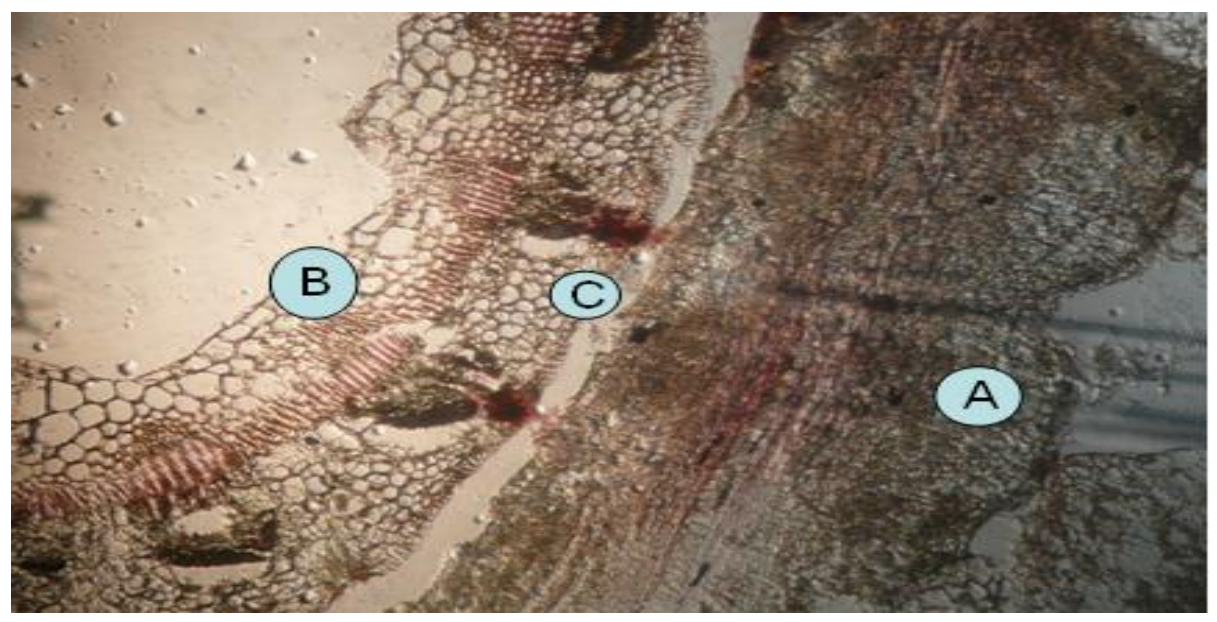

Fig. 1 : Histological reaction to Cuscuta planiflora of berseem (Helali cv.).

A: Haustorium of the dodder.

B: The host tissues.

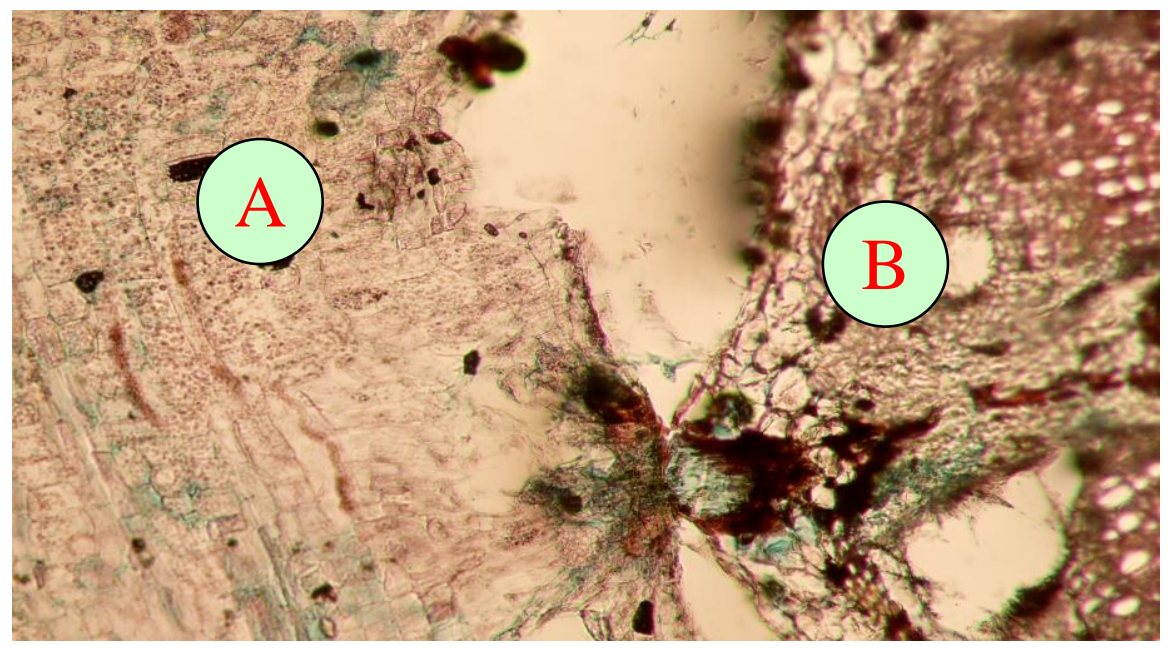

Fig. 2: Histological reaction to Cuscuta planiflora of berseem (Genotype no. 51).

A: Haustorium of dodder.

B: The host tissues.

It could be indicated from the presented data that different mechanisms were existed and it is suggested that the darkening of the tissue is a secondary symptom. It was developed as a result of various operations of different type of resistance/tolerance mechanisms that stopped or blocked the development of the parasite. With more detailed observations during the incompatible interaction of Cuscuta plantiflora with the tolerant berseem 
genotypes (Helali and Genotype no. 51), the intrusive cells of the parasite are stopped in the host cortex, before reaching the starch sheath were clear (Figs. 1 and 2).

In some cases, the parasite is scarcely able to pierce the epidermis, but lignifications of host peri-cycle and starch sheath has been observed in incompatible interactions between berseem genotypes and Cuscuta plantiflora, which seemed to prevent penetration of the parasite to the stem vascular cylinder (Fig. 3 and 4). These results are in agreement with those Goldwasser et al. (2001) they found that, in some cases, the houstorium developed in the cortex around the vascular cylinder but could not penetrate the cylinder itself as was previously shown in the O. aegyptiaca and Vicia spp.

In contrast, on the stems of the susceptible berseem genotypes, the infestation developed normally, with the intrusive cells reaching the center cylinder and the host vascular tissue (Figs. 5 and 6 ) in comparison with the control (Fig. 7).

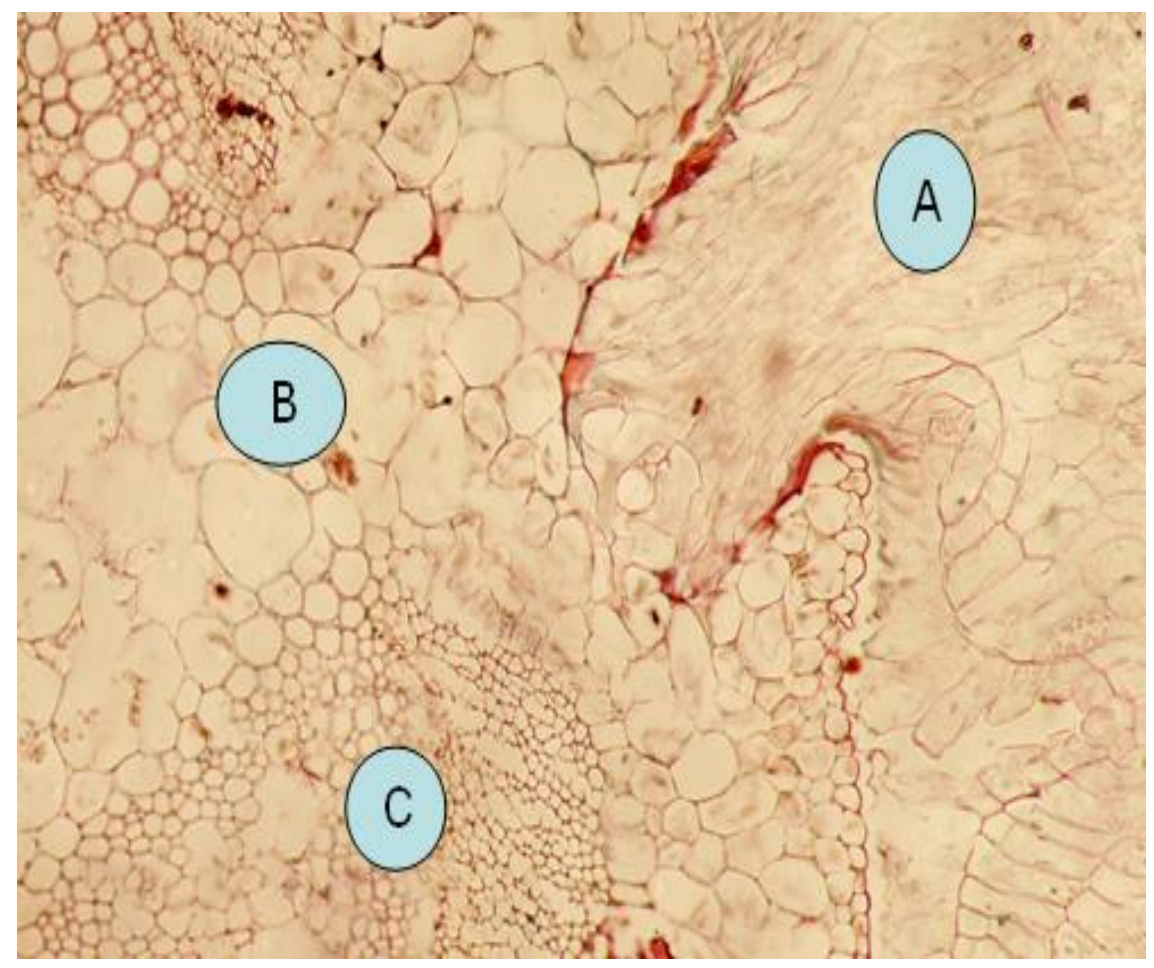

Fig. 3: Histological reaction to Cuscuta planiflora of berseem (Genotype no. 35)

A: Houstorium of the dodder B: The host tissue 


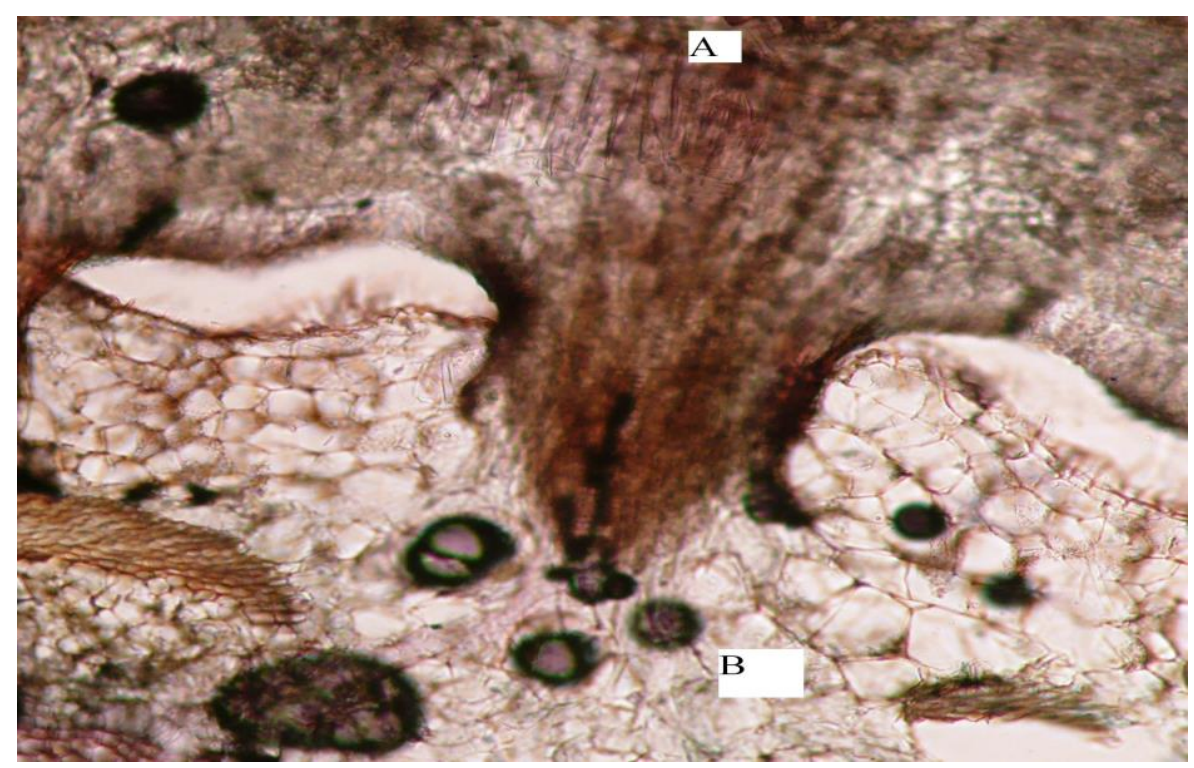

Fig. 4: Histological reaction to C. plantiflora of berseem (Genotype no. 74).

A: Houstorium of dodder.

B: The host tissue.

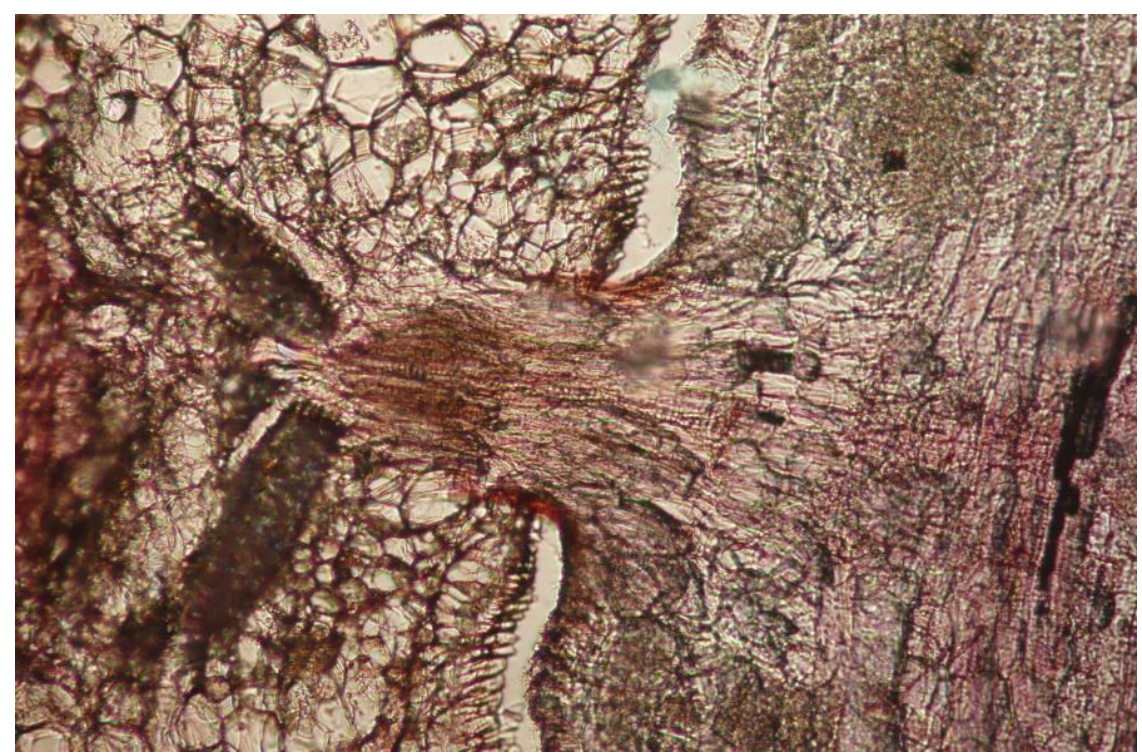

Fig. 5 : Histological reaction to C. planiflora of berseem (Genotype no. 94).

A: Houstorium of dodder

B: The host tissue 


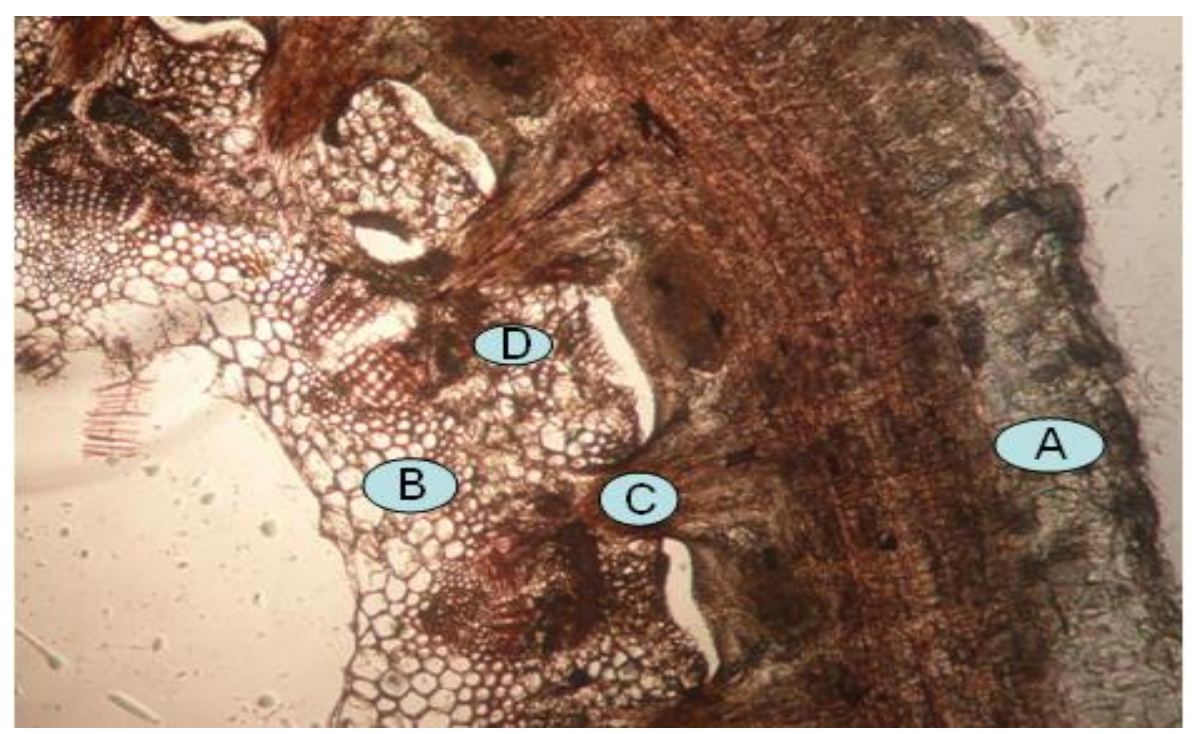

Fig. 6: Histological reaction to C. planiflora of berseem (Genotype no. 29).

A: Houstorium of dodder.

B: The host tissue.

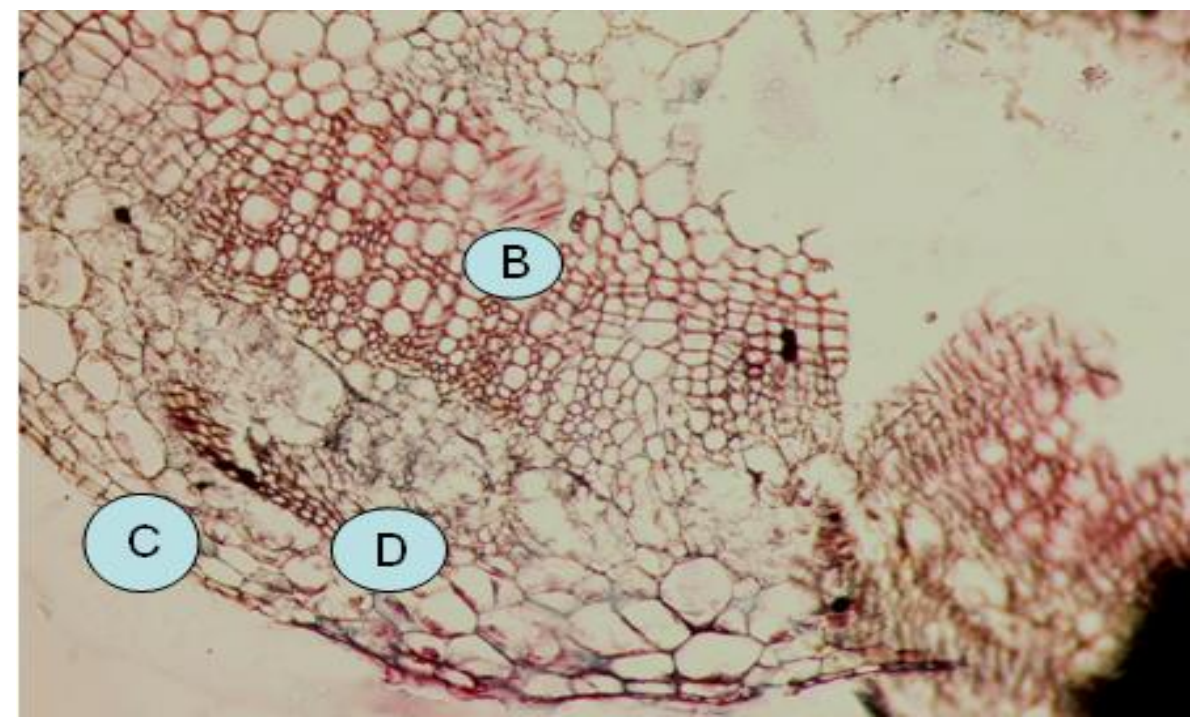

Fig. 7: Histological reaction to C. planiflora of berseem (Control/noninfested) 
El-Refaey, R. A. et al.

Usually, these substances are regarded as defensive materials or mechanisms from the host, but it would be possible to differentiate several substances in the C. planiflora berseem genotypes interaction that may play different roles and seem to originate from both the host and the parasite. The haustorium stem at the side of the host contacts which the host was formed by the expansion of the epidermis in tolerance varieties (Helali and Genotype no. 51), the cortex in moderate tolerance varieties (Genotypes no. 35 and 74) and the vascular cylinder in susceptible varieties (Genotypes no. 94 and 29). These results are in agreement with those obtained by Lee (1985) who reported that the portion of $C$. planiflora haustorium which lies external to the host was formed by the expansion of the epidermis and cortex of the stem at the contact side, and to have a group of meristematic cells within the haustorial cortex.

\section{Allelo-chemical compounds in berseem genotypes:}

Chemical analysis of eight berseem genotypes; Helali, Genotype no. 51, Genotype no. 35, Genotype no. 74, Genotype no. 65 , Genotype no. 14 , Genotype no. 94 and Genotype no. 29, for phenols compounds are presented in Table 1. It could be indicated from the results that the amount of phenolic acids were relatively high; 1111.65 and $965.24 \mu \mathrm{g} / 100 \mathrm{mg}$ of foliage dry weight for genotypes (Helali and no.51), respectively. Therefore, these varieties could retain some tolerance to the infestation with $C$. planiflora. Where, the phenolic acids in the genotypes no. 35 and 74 which are considered to some extend retain moderate tolerance to infestation with dodder were present in lesser concentration $(784.6$ and $735.38 \mu \mathrm{g} / 100 \mathrm{mg})$. While, in Genotypes no. 94 and 29 which could be considered susceptible varieties to infestation with dodder phenolic acids were found in trace amounts (386.64 and $423.02 \mu \mathrm{g} / 100 \mathrm{mg}$ dry weight, respectively). Also, it could be shown from the data that the amount of ferulic acid, and P-coumaric acid are relatively high which were represented by 864.65 and $191.75 \mu \mathrm{g} / 100$ $\mathrm{mg}$ in Helali cv. and 782.91 and $130.25 \mu \mathrm{g} / 100 \mathrm{mg}$ foliar dry weight, respectively. The amount of syringic, protecatechic and vanilic acids are present in lesser amounts. However, the other two P-hydroxyl benzoic acid and caffeic acid were presented in trace amount.

It worth mentioning that Genotypes no. 35 and 74 which are considered to retain moderate tolerance to dodder infestation had amount of ferulic acid was relatively high represented by $(784.60$ and $735.38 \mu \mathrm{g} / 100$ $\mathrm{mg}$ ) foliage dry weight of berseem associated with a lesser amount of Pcoumaric and syringic acids. While, Vanillic, P-hydroxyl benzoic, caffeic and protocatechuic acids were presented in trace amounts as foliar dry weight.

Concerning susceptible varieties (Genotypes no. 94 and 29), it could be indicated from the results that all the five phenolic acids were presented in trace amounts in a descending order; ferulic acid (1.22 and $1.56 \mu \mathrm{g} / 100 \mathrm{mg})$, P-coumaric acid $(2.68$ and $3.58 \mu \mathrm{g} / 100 \mathrm{~g})$, syringic acid (10.99 and 9.56 $\mu \mathrm{g} / 100 \mathrm{mg}$ ), vanilic acid $(4.71$ and $7.82 \mu \mathrm{g} / 100 \mathrm{mg}$ ) and P-hydroxyl benzoic acid $(14.67$ and $9.50 \mu \mathrm{g} / 100 \mathrm{mg})$ foliar dry weight, respectively. While, the two phenolic acids i.e. caffeic and protocatechuic acids were present in high amount as foliar dry weight. 
HPLC analysis revealed that the presence of protocatechuic acid, caffeic acid, P-hydroxyl benzoic acid, coumaric acid, ferulic acid, vanllic acid and syringic acid and their concentrations were different from genotype to another of berseem. In this respect, Chung and Miller (1995) mentioned that the water- soluble chemicals in alfalfa are mainly cinnamic acid and its derivatives such as ferulic acid, vanillic, hydrorybenzic, P-coumaric, transcinnamic acid and caffeic acid. Ali (2005) stated that tuber and foliar of Cyperus rotundus contained different flavonoids and phenolic compounds such as rutin, kaempforol, quercetin, myricatin, P-hydroxybenzoic acid, chlorogenic acid and ferulic acids. Inam et al. (1987) proved that amount of inhibitors identified in Xanthium strumarium shoots were caffeic acid, P. coumaric acid, P-hydroxy benzoic acid and ellagic acid.

We can conclude that even though resistance and/or tolerance amongand-within crop plants to pest, especially for parasitic weed like dodder is difficult to obtain, highly significant differences among the evaluated berseem genotypes for fresh and dry forage yields reduction percentages due to dodder infestation in all cuts and seasonal yields during the three winter seasons were detected. These differences are highly supported with obtaining less reduction percentages of fresh as well as dry forage yields for the tolerant berseem genotypes due to infestation with dodder. Indictor's traits which are highly associated i.e different histological structures among the susceptible and tolerant berseem genotypes and allelo chemical compounds which existed in different concentrations well performed for tolerant genotypes in comparison with the sensitive ones were evident in this study.

Table 1: Phenolic compounds in berseem varieties

\begin{tabular}{|c|c|c|c|c|c|c|c|c|}
\hline \multirow{2}{*}{$\begin{array}{c}\text { Phenolic } \\
\text { compounds }\end{array}$} & \multicolumn{7}{|c|}{ Concentration $(\mu \mathrm{g} / \mathbf{1 0 0} \mathbf{~ m g})$ foliar dry weight } \\
\cline { 2 - 9 } & Helali & $\begin{array}{c}\text { Gen. } \\
\text { no. 51 }\end{array}$ & $\begin{array}{c}\text { Gen. } \\
\text { no. 35 }\end{array}$ & $\begin{array}{c}\text { Gen. } \\
\text { no. 74 }\end{array}$ & $\begin{array}{c}\text { Gen. } \\
\text { no. 65 }\end{array}$ & $\begin{array}{c}\text { Gen. } \\
\text { no. 14 }\end{array}$ & $\begin{array}{c}\text { Gen. } \\
\text { no. 94 }\end{array}$ & $\begin{array}{c}\text { Gen. } \\
\text { no. 29 }\end{array}$ \\
\hline $\begin{array}{c}\text { Protocatechu } \\
\text { ic acid }\end{array}$ & 16.32 & 11.05 & 12.32 & 2.52 & 24.13 & 32.32 & 210.47 & 240.11 \\
\hline Caffeic acid & 3.18 & 2.67 & 15.05 & 3.40 & 9.58 & 6.14 & 141.90 & 150.89 \\
\hline $\begin{array}{c}\text { P-hydroxyl } \\
\text { benzoic acid }\end{array}$ & 8.58 & 10.32 & 13.30 & 9.15 & 12.46 & 6.32 & 14.67 & 9.50 \\
\hline Vanillic acid & 10.77 & 11.80 & 13.34 & 6.34 & 34.46 & 48.22 & 4.71 & 7.82 \\
\hline Syringic acid & 16.40 & 16.24 & 25.75 & 18.64 & 13.75 & 11.66 & 10.99 & 9.56 \\
\hline $\begin{array}{c}\text { Coumaric } \\
\text { acid }\end{array}$ & 191.75 & 130.25 & 58.40 & 83.68 & 54.23 & 73.47 & 2.68 & 3.58 \\
\hline Ferulic acid & 864.65 & 782.91 & 636.44 & 611.65 & 411.53 & 401.77 & 1.22 & 1.56 \\
\hline Total & 1111.65 & 965.24 & 784.60 & 735.38 & 560.14 & 579.90 & 386.64 & 423.02 \\
\hline
\end{tabular}

\section{REFERENCES}


El-Refaey, R. A. et al.

Abd El-Wahed, R. (1996). Studies on the effect of certain herbicides of dodder C. spp. control in certain leguminous crops. Ph. D. Thesis, Fac. Agric. Cairo Univ.

Ali, I. H. H. (2005). Allelopathic effects of purple nut-sedge (Cyperus rotundus L) weed on some weed species. Annals of Agric. Sci., Cairo, 50(1): 123-134.

Al-Menoufi, O. A. and F. M. Ashton (1991). Studies on the parasitism of Cuscuta spp. Series 8: susceptibility and resistance of some Lycopersicon species to Cuscuta pentagona infection. pp.293-297. in: proc. $5^{\text {th }}$ internet. Sym. Parasitic weeds, Nairobi. Kenya. Ashton, F.M and D. Santana. 1976. Cuscuta spp. (Dodder) A.

Chon, S.U.(2004). Phytotoxic effect of Xanthium occidentale leaf extract on seed germination and early seedling growth of alfalfa and barnyard grass. Korean J. Crop Sci. 49(1): 30-35.( C F Computer Search).

Chung, I. M. and D. A. Miller (1995). Effect of alfalfa plant and soil extracts on germination and growth of alfalfa. Agron. J., 87: 762-767.

Chung, I. M.;K.H. Kim; J. K. Ahn; S.C. Chun; C.S. Chun; C.S. Kim; J.T Kim and S.h. Kim (2002). Screening of allele-chemicals on barnyardgras Echinochola crus-galli and identification of potentially allelopathic compounds from rice ( Oryza sativa L.) variety hull extracts. Crop Port., 21:913-920.

Dorr, I. (1987). The haustorium of Cuscuta - new structural results. P. 163170. In; Proc. $4^{\text {th }}$ Inernat. Sym. Parasitic Flowering Plants, Marburg, Germany. ( C F Computer Search).

Farah, A. F. and J. M. El-Hassan (2002). Anatomical mechanisms of resistance o field dodder (Cuscuta campestris Yuncker) on some horticultural and field crops. U. of K. J. Agric. Sci. 10 (1), 77-93. ( C F Computer Search).

Fayaad, A.H.; K.M. Hameed and H. A. Al-Ani (1990). Blight of dodder Cuscuta campertries Yunck casued by Alternara alternara Fr. Keissler and Geotrichum candidum Link. Ex Pers. Arab J. of Plant Protection, 8 (1): 45-59.

Goldwasser, Y.; R. L.Worobel and W. T. Lanini (2001). Tolerance of tomato varieties to lespedeza dodder. Weed Sci., 49:520 - 523.

Hall, M. H. and P. R. Henderlong (1989): Alfalfa autotoxic fraction characterization and initial separation. Crop Sci., 29(2): 425-428.

Hegazy, A. K.; A. Elfiky and H. F. Kabiel (2005). Spatial pattern and mulching effect of Anastatica hierochuntica L. on structure and function of some desert plants. Fourth World Congress on Allelopathy p. 6.

Inam, B.; F. Hussain and F. Bano (1987). Allelopathic effects of Pakistani weeds Xanthium strumarium L. Pakistan J. of Scientific and Industrial Res., 30 (7) :530-533.

Joel, D. M.; D. Losner-Goshen, J. Hershenhorn, Y. Goldwasser, M. Assayag (1996). The haustorium and its development in compatible and resistant host. In: Moreno MT, Cubero Jl, Berner D, Joel D, 
Musselman LJ, Parker C, eds. Advances in parasitic plant research. Sevilla, Spain: Junta de Andalucía, Consejería de Agricultura y Pesca, 531-541. (C F Computer Search).

Khanh, T. D.; T. D. Xuan and I. M. Chung (2007). Rice allelopathy and the possibility for weed management. Annals of Applied Biology., 151(3):325-339.

Kim, K.U. and D.H. Shin (2003).: The importance of allelopathy in breeding new cultivars. Weed management for developing countries. FAO plant production and protection paper. Addendum, J. pp. 195-210. (C F Computer Search).

Kim, K. W.; K. U. Kim; D. H. Shin; I. J. Lee; H. Y. Kim; J. C. Kor and S. H. Nam (2000). Searching for allelochemicals from the allelopathic rice cultivar, Kouketsumachi.Korean J. of Weed Sci. 20(3):197-207. (C F Computer Search).

Leather; G. R. and F. A. Einhelling (1985). Mechanism of allelopathic action in bioassay. In the chemistry of Allelopathy-Biochemical Interactions among plants, (A.C.Thompson,ed) pp. 197-205. Amer. Chem. Soci., Washington, USA. (C F Computer Search).

Lee, C. C. (1985). Studies on the haustorium of Cuscuta japonica Choisy1, the upper haustorium. Korean J. of Botany, 28 (4): 261 -270. (C F Computer Search).

Liu, D. L. and J. V. Lovett (1993). Biologically active secondary metabolites of barley II: Phytotoxicity of barley allelochemicals. J. Chem. Ecol.; 19: 2231-2244.

Mattice, J.; T. Lavy; B. Skulman and R. H. Dilday (1997). A search for the allelochemicals in rice responsible for the control of ducksalad. In: allelopathy in rice (M. Olofsdotter ed.). International Rice Research Institute, in press.

McKeehen, J. D.; R. H. Busch and R. G. Fulcher (1999). Evaluation of wheat (Triticum aestivum L.) phenolic acids during grain development and their contribution to Fusarium resistance. J. Agric. Food Chem., 47: 1476-1482.

Noguchi, H. K. and T. Ino (2005). Allelochemical momilactone B from rice plants. Proc. of the $4^{\text {th }}$ World Congress on Allelopathy, "Establishing the Scientific Base", Wagga Wagga, New South Wales, Australia; 525528.

Press, M. C.; J. D. Graves and G. R. Stewart (1990). Physiology of the interaction of angiosperm parasites and their higher plant hosts. Plant Cell and Environ. 13:91-104.

Rasmussen, J.; J. I. Kurtzmann and A. Jensen (2004). Tolerance of competitive spring barely cultivars to weed harrowing. Weed Res., 44(6): 446-452.

Rimando, A. M.; M. Olofsdotter; F. E. Dayan and S. O. Duke (2001). Searching for rice allelochemicals: an example of bioassay-guided isolation. Agron. J., 93: 16-20.

Ruzin, S.E. (1991): Plat micro technique and microscopy Oxford: Oxford Univ., Press. 


\section{El-Refaey, R. A. et al.}

Snell, F.D. and C.T. Snell (1953): Colorimetric Methods. Volume III Organic. 606 pp. D. Van Nostrand Company, Inc, Toronto, New York, London.

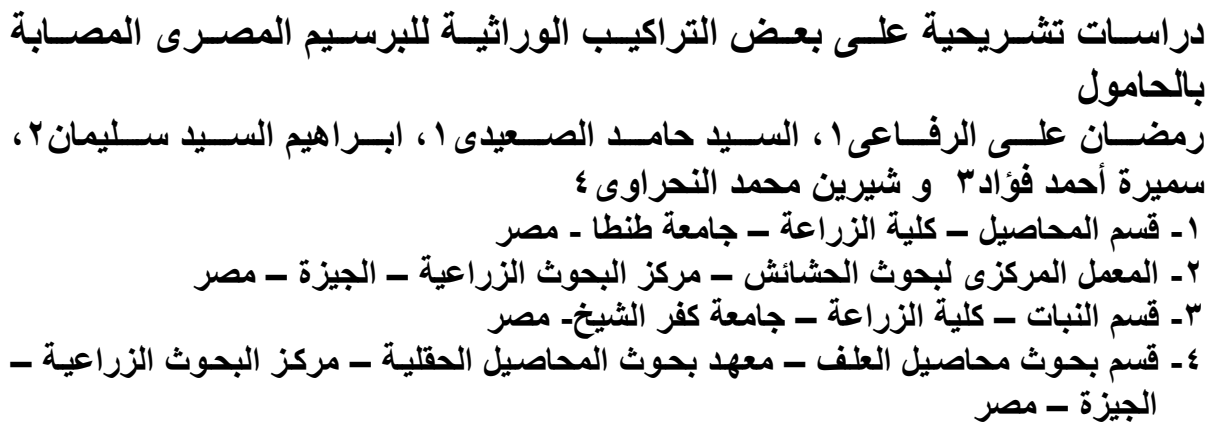


J. Plant Production, Mansoura Univ., Vol. 5 (7), July, 2014 